\title{
Genetic Analysis for Growth and Yield Traits of Different Genotypes of Pea (Pisum sativum L.) under Prayagraj agro-climatic Condition
}

\author{
Jai Vardhan Raj*, V. M. Prasad, Vijay Bahadur, Rajneesh Srivastava and Devi Singh \\ Department of Horticulture Sam Hinggin Bottom University of Agriculture, Technology and \\ Sciences, Prayagraj, India \\ *Corresponding author
}

\begin{abstract}
A B S T R A C T
The present investigation was conducted during Rabi seasons of 2014-15 and 2015-16 at the experimental field of Department of Horticulture, Prayagraj School of Agriculture, Sam Higginbottom University of Agriculture Technology and Sciences, Prayagraj The analysis of variance revealed that mean squares due to genotypes were significant for all the characters during both the years which indicated that, considerable genetic variation among the genotypes for all the traits. The genotypes viz., VRP-22, VRP-5, KS-156, Azad Pea and VRP-7 were found promising for growth characters during both the years. The genotypes namely, KS-156, VRP-22, Azad Pea-3, VRP-5 and KS-149 were found superior for pod yield and its attributes. The estimates of PCV were higher than corresponding GCV for all characters studied which indicated that the apparent variation is not only due to genotypes but, also due to the influence of environment. High heritability coupled with high genetic advance were observed for pod yield per plant, height of plants, number of branches per plant, number of pods per plant, protein and ash content during both the years which revealed that these characters are governed by additive gene action and phenotypic selection would be effective for the improvement of characters.
\end{abstract}

Keywords

Genetic variability, Heritability, Genetic advance, and pod yield

Article Info

Accepted:

05 February 2020

Available Online:

10 March 2020

\section{Introduction}

Garden pea [Pisum sativum L. var. hortense, $2 n=2 x=14$ ], is an important vegetable belongs to the family Fabaceae. It is harvested in immature stage for table purpose and to be cooked as green peas to provide a delicious dish, or to be canned or frozen for subsequent uses. India ranks third in area after China and USSR under pea (vegetable and pulse pea) cultivation. In India, the total area covered by pea is 0.46 million hectare with the production of 4.24 million tonnes whereas, productivity is 9.5 tonne per hectare. It is grown extensively in Uttar Pradesh, Madhya Pradesh, Himachal Pradesh, Punjab, Haryana, 
Rajasthan, Maharashtra, Bihar and Karnataka, contributing to $67 \%$ of the total production (Anonymous, 2016).

Evaluation of germplasm is the basic tool for identification of important genotypes. The great extent of natural variation available for various characters among the genotypes suggests good scope for improvement in economic traits. Large variability ensures better chance of producing new forms. Variability parameters like genotypic and phenotypic coefficient of variations, heritability and genetic advance, is of paramount significance in formulating an appropriate breeding strategy aimed at exploiting the inherent variability of the original population. Phenotypic variability changes under different environmental conditions, while genetic variability remains unchanged and more useful to a plant breeder for exploitation in selection or hybridization. The correlation studies provide information about association between any two characters. Knowledge of correlation among different traits and further portioning them into direct and indirect effects is one of approaches to understand nature and extent of such relationship. Currently the pea production per unit area is low as compare to china, the many reason for low productivity in India is use of local varieties and traditional cultivation methods followed by the farmers. To increase the productivity of garden pea and look out the effect of most survival varieties under Prayagraj agro-climatic condition.

\section{Materials and Methods}

The investigation entitled "Genetic Analysis for qualitative and quantitative traits of different genotypes of pea (Pisum sativum L.) under Prayagraj agro-climatic condition" was conducted during Rabi seasons of 2014-15 and 2015-16 at the experimental field of Department of Horticulture, Prayagraj School of Agriculture, Sam Higginbottom University of Agriculture Technology and Sciences, Prayagraj. The experimental material for the present investigation comprised twenty genotypes of garden pea collected from different places in India and being maintained at Department of Horticulture, Prayagraj School of Agriculture, Sam Higginbottom University of Agriculture Technology and Sciences, Prayagraj (U.P.) Table-1.

The experiments were laid out in Randomized Block Design with 20 treatments replicated thrice. The observations were recorded on characters viz., height of plants $(\mathrm{cm})$, number of branches per plant, pod width $(\mathrm{cm})$, number of pods per plant, pod length $(\mathrm{cm})$, number of grains per pod, number of nodes per plant, pod yield ( $\mathrm{t} / \mathrm{ha}$ ), on five randomly selected plants during both the yeas. The observations recorded on the five plants were summed up and divided by five to get mean value. The experimental data was compiled by taking the mean value of the twenty genotypes of pea garden for eight yield and its components traits from all the three replications. Then it was subjected to the statistical analyses to the procedure outlined by Panse and Sukhatme (1967).

\section{Results and Discussion}

The continuous variation exhibited by quantitative traits with which the breeders have to deal with, include the heritable and non-heritable components. Though, it is difficult to assess the genotype directly but it is possible through the assessment of phenotypic expression (which is an outcome of interplay of the genotype and environment) in the existing material and thus, the study of phenotypic variability for yield and its component traits is very important.

The analysis of variance (Table 2) revealed that mean squares due to genotypes were 
significant for the traits viz., height of plants (cm), number of branches per plant, pod width $(\mathrm{cm})$, number of pods per plant, pod length $(\mathrm{cm})$, number of grains per pod, number of nodes per plant, pod yield (t/ha), T.S.S, protein (\%), ascorbic acid (mg/ 100g), ash content (\%) and moisture (\%) which indicated that considerable genetic variation among the genotypes for all the traits. Sufficient genetic variability for many traits has also been reported by earlier workers viz., Kumar et al., (2010), Sharma et al., (2011) and Katoch et al., (2015) thereby, supporting the present findings.

In $\mathrm{Y}_{1}$ (2014-15) perusal of table 2 revealed that three genotypes viz., VRP-22 $(106.33 \mathrm{~cm})$, KS-156 $(94.00 \mathrm{~cm})$ and VRP-5 $(96.33 \mathrm{~cm})$ were significantly superior to check (Arkel). The genotypes exhibited an average plant height of $79.47 \mathrm{~cm}$ with a range of $40.67 \mathrm{~cm}$ to $106.33 \mathrm{~cm}$. Similarly, In $\mathrm{Y}_{2}(2015-16)$ The genotypes exhibited an average plant height of $75.38 \mathrm{~cm}$ with a range of $39.24 \mathrm{~cm}$ to $101.02 \mathrm{~cm}$ and only one genotype KS-156 $(101.02 \mathrm{~cm})$ was significantly superior to check (Arkel). Higher pod yield in taller plants could be attributed due to production of more number of pods per plant. The findings are in accordance with earlier researchers (Alam et al., 2010 and Khan et al., 2013).

The number of branches per plant varied from 7.25 (PMR-71) to 14.57 (VRP-22) and with overall mean 12.28 and 6.81 (PMR-71) to 14.18 (KS-156) with grand mean 11.58 branches per plant In $\mathrm{Y}_{1}$ and $\mathrm{Y}_{2}$, respectively. The genotypes namely VRP-22 and KS-156 produced high number of branches per plant during both the years. The more number of branches could be attributed to increasing number of pods per plant which lead to higher pod production. The genotypes showed significance differences among the also reported by Gupta and Singh (2007). The number of nodes per plant ranged from 15.54,
14.64 to 23.18 , and 22.02 with mean 19.39. 18.42 In $Y_{1}$ and $Y_{2}$, respectively. The maximum number of nodes per plant were recorded in genotype VRP-22 (23.18) followed by VRP-5 (22.47), Azad Pea-4 (21.26), KS-156 (20.83) and VRP-7 (20.40) in $\mathrm{Y}_{1}$ and in $\mathrm{Y}_{2} \mathrm{KS}-156$ (22.02) followed by Azad Pea-3 (21.17), Azad Pea-4 (20.19), PRP-801 (20.10) and Azad Pea-2 (19.38).The present findings are in accordance of earlier research workers viz., Ramesh and Tewata (2002) and Arya et al., (2004).

The number of pods per plant directly influenced the yield potential of a genotype. A wide range of genetic variability existed for this character among the genotypes under study. In $\mathrm{Y}_{1}$ (Table-3), maximum number of pods per plant were produced by VRP-22 (29.13) followed by VRP-7 (26.13), Azad Pea-4 (23.69), VRP-5 (23.69) and Vivek Mater (23.19). Minimum number of pods per plant were recorded in PMR-71 (12.43) followed by KS-501 (13.69). Nine genotypes produced significantly higher number of pods than check (Arkel). The pods per plant varied from 12.43 to 29.13 with grand mean 19.77. Similarly in $\mathrm{Y}_{2}$, maximum number of pods per plant were produced by KS-156 (27.67) followed by VRP-7 (24.82), Azad Pea-3 (24.00), Azad Pea-4 (22.87) and Vivek Mater (22.04). Minimum number of pods per plant were recorded in KS-501 (13.15) followed by PMR-71 (13.97). Eight genotypes produced significantly higher number of pods than check (Arkel). The pods per plant varied from 13.15 to 27.67 with grand mean 19.11. Genetic variability for this character has also been observed by Singh and Singh (2011).

The mean values of genotypes (Table-3) revealed that in $Y_{1}$, and $Y_{2}$ genotype E-6 had the maximum pod length 9.77 and $9.27 \mathrm{~cm}$, respectively, The pod length varied from 7.98 $\mathrm{cm}$ to $9.77 \mathrm{~cm} \mathrm{~cm}$.and7.57 $\mathrm{cm}$ to $9.27 \mathrm{~cm}$ with general mean 8.93 and $8.46 \mathrm{~cm}$ in $\mathrm{Y}_{1}$ and 
$\mathrm{Y}_{2}$, respectively. Genetic variability for this character has also been observed by Pani et al., (2001), Habib and Zamin (2003) and Kalloo et al., (2005).

The mean values of genotypes (Table-3) revealed that in $\mathrm{Y}_{1}$, genotype Azad Pea-1 had the maximum pod width $(1.69 \mathrm{~cm})$ followed by KS-205 $(1.65 \mathrm{~cm})$, Azad Pea-1 $(1.57 \mathrm{~cm})$, Vivek Mater-10 $(1.53 \mathrm{~cm})$ and VRP-6 (1.46 $\mathrm{cm})$. The minimum pod width was recorded in Arkel $(1.12 \mathrm{~cm})$ followed by E-6 $(1.15 \mathrm{~cm})$ $\mathrm{KS}-156$ and $\mathrm{KS}-501(1.28 \mathrm{~cm})$. The pod width varied from $1.12 \mathrm{~cm}$ to $1.69 \mathrm{~cm}$ with general mean $1.39 \mathrm{~cm}$.

In $\mathrm{Y}_{2}$, the maximum pod width was observed in genotype Azad Pea-1 $(1.61 \mathrm{~cm})$ followed by KS-205 $(1.54 \mathrm{~cm}), \mathrm{KS}-149(1.48 \mathrm{~cm})$, Vivek Mater-10 (1.46 cm) and VRP-6 (1.38 $\mathrm{cm})$. The minimum pod width was recorded in VRP-7 $(1.05 \mathrm{~cm})$ followed by E-6 (1.09 $\mathrm{cm})$ and $\mathrm{KS}-501(1.20 \mathrm{~cm})$. The pod width varied from $1.05 \mathrm{~cm}$ to $1.61 \mathrm{~cm}$ with general mean $1.33 \mathrm{~cm}$.

Number of grains per pod and number of pods directly influence the yield potential of a genotype. A wide range of genetic variability existed for this character among the genotypes under investigation. In $\mathrm{Y}_{1}$ the pods per plant varied from 6.13 to 8.51 with grand mean 7.33.None of the genotypes produced significantly higher number of seeds per pod than check (Arkel). whereas, In $\mathrm{Y}_{2}$ Two genotypes (E-6 and KS-501) produced significantly higher number of seeds per pod than standard check (Arkel). The number of seeds per pod varied from 6.13 to 8.51 with grand mean 7.32. Genetic variability for this character has also been observed by Murtaza et al., (2007); Singh and Singh (2011) and Singh et al., (2012).

In $Y_{1}$ perusal of results in Table- 3 revealed that maximum pod yield was produced by genotype KS-156 (15.66 t/ha, $14.76 \mathrm{t} / \mathrm{ha})$ followed by VRP-22 (15.03 t/ha,14.28 t/ha), Azad Pea-3 (14.14 t/ha, 13.43 t/ha), Minimum pod yield was recorded in PMR-71 (3.99 t/ha, $3.85 \mathrm{t} / \mathrm{ha}$ ), respectively. Eleven genotypes found significantly superior to check (Arkel). The green pod yield $\mathrm{t} / \mathrm{ha}$ varied from 3.99 to 15.66 with overall mean $10.03 \mathrm{t} / \mathrm{ha}$. In $\mathrm{Y}_{1}$ and in $\mathrm{Y}_{2}$ the pod yield (t/ha) varied from 3.85 to 14.76 with grand mean 9.54 . These results are in agreement with the findings of earlier research workers viz., Murtaza et al., (2007); Sharma et al., (2010) and Chadha et al., (2013).

\section{Components of variability}

Various parameters of variability have been calculated from the data viz., coefficient of variation at phenotypic (PCV) and genotypic (GCV) levels along with heritability $\left(h^{2}\right)$ in broad sense and genetic advance (GA) as per cent of mean for different characters. To ascertain the nature and magnitude of observed variability in the hybrids, it was partitioned into phenotypic, genotypic and environmental components. The knowledge of phenotypic coefficient of variation (PCV) and genotypic coefficient of variation (GCV) is helpful in predicting the amount of variation present in the given genetic stock, which in turn helps in formulating an efficient breeding programme. The estimates of PCV were higher than corresponding GCV for all characters studied which indicated that the apparent variation is not only due to genotypes but, also due to the influence of environment.

In $\mathrm{Y}_{1}$, the high estimates of phenotypic as well as genotypic coefficient of variation were observed for pod yield (35.34 and 34.92 $\%$ ), number of pods per plant (23.43 and $23.19 \%)$ and height of plants (20.86 and $20.49 \%)$. Whereas, high estimates of PCV (20.09\%) observed in ash content. Moderate 
PCV and GCV values were obtained for protein (18.91 and $18.44 \%$ ) and number of branches per plant (15.26 and $15.10 \%)$. While, the only moderate estimates of PCV were observed for number of grains per pod (12.49\%), T.S.S. (12.15\%), pod width (12.08 $\%)$, number of nodes per plant $(10.72 \%)$ and ash content had high estimates of GCV (18.85 $\%)$ only. However, the rest of the characters showed low estimates of PCV and GCV.

In $\mathrm{Y}_{2}$, the high estimates of phenotypic as well as genotypic coefficient of variation were observed for pod yield (35.39 and 34.97
$\%)$, number of pods per plant (22.04 and $21.65 \%$ ) and height of plants (20.66 and $20.26 \%)$. Whereas, high estimates of PCV (20.16) showed by ash content only. Moderate PCV and GCV values were observed for protein (18.65 and $18.39 \%$ ) and number of branches per plant (16.25 and $16.13 \%)$. While, the only moderate estimates of PCV were observed for T.S.S. (12.09\%), pod width $(11.32 \%)$, number of grains per pod $(10.63 \%)$ and number of nodes per plant $(10.63 \%)$. However, the rest of the characters showed low estimates of PCV and GCV.

Table.1 List of garden pea genotypes used for the study and their source of origin

\begin{tabular}{|c|l|l|l|l|l|}
\hline $\mathbf{S .}$ N. & $\begin{array}{l}\text { Name of } \\
\text { genotypes }\end{array}$ & Source of origin & $\begin{array}{l}\text { S. } \\
\text { N. }\end{array}$ & $\begin{array}{l}\text { Name of } \\
\text { genotypes }\end{array}$ & Source of origin \\
\hline $\mathbf{1}$ & Vivek Mater-10 & VPKAS, Uttarakhand & 11 & PRP-801 & ICAR-IIVR, Varanasi \\
\hline $\mathbf{2}$ & E-6 & PAU, Ludhiana & 12 & KS-205 & ICAR-IIVR, Varanasi \\
\hline $\mathbf{3}$ & Azad Pea-1 & C.S.A. U A \& T. Kanpur & 13 & KS-501 & ICAR-IIVR, Varanasi \\
\hline $\mathbf{4}$ & Azad Pea-2 & C.S.A. U A \& T. Kanpur & 14 & KS-156 & ICAR-IIVR, Varanasi \\
\hline $\mathbf{5}$ & Azad Pea-3 & C.S.A. U A \& T. Kanpur & 15 & KS-210 & ICAR-IIVR, Varanasi \\
\hline $\mathbf{6}$ & Arkel & IARI, New Delhi & 16 & VRP-6 & ICAR-IIVR, Varanasi \\
\hline $\mathbf{7}$ & Azad Pea-4 & C.S.A. U A \& T. Kanpur & 17 & VRP-5 & ICAR-IIVR, Varanasi \\
\hline $\mathbf{8}$ & PBP-4 & PAU, Ludhiana & 18 & VRP-7 & ICAR-IIVR, Varanasi \\
\hline $\mathbf{9}$ & KS-149 & ICAR-IIVR, Varanasi & 19 & VRP-9 & ICAR-IIVR, Varanasi \\
\hline $\mathbf{1 0}$ & PMR-71 & ICAR-IIVR, Varanasi & 20 & VRP-22 & ICAR-IIVR, Varanasi \\
\hline
\end{tabular}

Table.2 Analysis of variance (mean sum of squares) for eight characters in vegetable pea under Prayagraj agro-climatic condition during Rabi season, 2014-15 ( $\left.\mathrm{Y}_{1}\right)$ and 2015-16 ( $\left.\mathrm{Y}_{2}\right)$

\begin{tabular}{|c|c|c|c|c|c|c|c|c|c|c|}
\hline $\begin{array}{l}\text { Characters } \\
\text { Source of } \\
\text { Variations }\end{array}$ & df & Year & $\begin{array}{l}\text { Height of } \\
\text { plant }(\mathrm{cm})\end{array}$ & $\begin{array}{c}\text { No. of } \\
\text { branches } \\
\text { / plant }\end{array}$ & $\begin{array}{l}\text { Pod } \\
\text { width } \\
(\mathrm{cm})\end{array}$ & $\begin{array}{l}\text { No. of } \\
\text { pods / } \\
\text { plant }\end{array}$ & $\begin{array}{l}\text { Pod } \\
\text { length } \\
\text { (cm) }\end{array}$ & $\begin{array}{l}\text { No. of } \\
\text { grains } \\
\text { / pod }\end{array}$ & $\begin{array}{l}\text { No. of } \\
\text { nodes / } \\
\text { plant }\end{array}$ & $\begin{array}{l}\text { Pod } \\
\text { Yield } \\
\text { (t/ha) }\end{array}$ \\
\hline \multirow[t]{2}{*}{ Replication } & \multirow[t]{2}{*}{2} & $\mathrm{Y}_{1}$ & 5.13 & 0.16 & 0.00 & 0.78 & 0.05 & 0.12 & 1.28 & 0.63 \\
\hline & & $\mathrm{Y}_{2}$ & 7.06 & 0.08 & 0.01 & 0.05 & 0.12 & 0.09 & 1.17 & 0.57 \\
\hline \multirow[t]{2}{*}{ Treatments } & \multirow[t]{2}{*}{19} & $\mathrm{Y}_{1}$ & $804.83 * *$ & $10.39 * *$ & $0.06 * *$ & $63.52 * *$ & $1.05 * *$ & $1.47 * *$ & $11.14 * *$ & $37.14 * *$ \\
\hline & & $\mathrm{Y}_{2}$ & $709.08 * *$ & $10.52 * *$ & $\begin{array}{c}0.05^{*} \\
*\end{array}$ & $\begin{array}{c}51.98 * \\
*\end{array}$ & $0.84 * *$ & $1.47 * *$ & $9.87 * *$ & $33.63 * *$ \\
\hline \multirow[t]{2}{*}{ Error } & \multirow[t]{2}{*}{38} & $Y_{1}$ & 9.71 & 0.07 & 0.01 & 0.43 & 0.04 & 0.52 & 0.90 & 0.30 \\
\hline & & $Y_{2}$ & 9.29 & 0.05 & 0.01 & 0.61 & 0.15 & 0.23 & 0.82 & 0.27 \\
\hline
\end{tabular}

*,** - Significant at $5 \%$ and $1 \%$ probability level, respectively. 
Table.3 Mean performance of twenty genotypes for eight characters in vegetable pea under Prayagraj agro-climatic condition during Rabi season, 2014-15 (Y1) and 2015-16 (Y2)

\begin{tabular}{|c|c|c|c|c|c|c|c|c|c|c|c|c|c|c|c|c|c|}
\hline \multirow{2}{*}{\multicolumn{2}{|c|}{$\begin{array}{l}\text { Characters } \\
\text { Genotypes }\end{array}$}} & $\begin{array}{l}\text { Heigh } \\
(\mathrm{cm})\end{array}$ & of plan & $\begin{array}{l}\text { bran } \\
\text { / plar }\end{array}$ & hes & \multicolumn{2}{|c|}{$\begin{array}{l}\text { Pod width } \\
\text { (cm) }\end{array}$} & \multicolumn{2}{|c|}{$\begin{array}{l}\text { Number of } \\
\text { pods / plant }\end{array}$} & \multicolumn{2}{|c|}{$\begin{array}{l}\text { Pod length } \\
\text { (cm) }\end{array}$} & \multicolumn{2}{|c|}{$\begin{array}{l}\text { No. of } \\
\text { grains / } \\
\text { pod }\end{array}$} & \multicolumn{2}{|c|}{$\begin{array}{l}\text { No. of nodes } \\
\text { per / }\end{array}$} & \multicolumn{2}{|c|}{$\begin{array}{l}\text { Pod Yield } \\
\text { (t/ha) }\end{array}$} \\
\hline & & Y1 & Y2 & Y1 & Y2 & Y1 & Y2 & Y1 & Y2 & Y1 & Y2 & Y1 & Y2 & Y1 & Y2 & Y1 & Y2 \\
\hline \multicolumn{2}{|c|}{ V. Mater-10 } & 69.17 & 65.71 & 9.85 & 11.78 & 1.53 & 1.46 & 23.19 & 22.04 & 7.98 & 7.58 & 7.16 & 7.12 & 19.33 & 18.37 & 7.17 & 7.83 \\
\hline \multicolumn{2}{|l|}{ E-6 } & 79.60 & 75.62 & 12.40 & 11.78 & 1.15 & 1.09 & 23.13 & 13.59 & 9.77 & 9.27 & 8.26 & 8.26 & 20.04 & 19.04 & 12.49 & 11.87 \\
\hline \multicolumn{2}{|c|}{ Azad Pea-1 } & 51.10 & 48.54 & 8.45 & 7.68 & 1.69 & 1.61 & 14.83 & 14.18 & 9.20 & 8.74 & 6.73 & 6.73 & 18.62 & 17.69 & 5.08 & 4.82 \\
\hline \multicolumn{2}{|c|}{ Azad Pea-2 } & 89.67 & 85.56 & 13.19 & 12.67 & 1.57 & 1.37 & 19.96 & 18.12 & 8.04 & 8.27 & 6.45 & 7.66 & 17.41 & 19.38 & 7.29 & 6.81 \\
\hline \multicolumn{2}{|c|}{ Azad Pea-3 } & 92.00 & 88.57 & 13.33 & 12.68 & 1.35 & 1.28 & 14.93 & 24.00 & 8.55 & 7.98 & 6.13 & 8.04 & 19.61 & 21.17 & 14.14 & 13.43 \\
\hline \multicolumn{2}{|c|}{ VRP-22 } & 106.33 & 87.40 & 14.57 & 12.67 & 1.43 & 1.30 & 29.13 & 19.76 & 9.54 & 8.24 & 7.86 & 6.13 & 23.18 & 18.64 & 15.03 & 14.28 \\
\hline \multicolumn{2}{|c|}{ Azad Pea-4 } & 87.67 & 83.28 & 12.40 & 13.11 & 1.36 & 1.29 & 25.26 & 22.87 & 8.30 & 7.89 & 7.06 & 7.06 & 21.26 & 20.19 & 11.28 & 10.72 \\
\hline \multicolumn{2}{|l|}{ PBP-4 } & 67.67 & 64.28 & 13.26 & 9.89 & 1.44 & 1.37 & 19.08 & 18.07 & 9.67 & 9.19 & 6.93 & 6.93 & 18.62 & 17.69 & 8.24 & 4.96 \\
\hline \multicolumn{2}{|l|}{ KS-149 } & 81.00 & 84.48 & 13.33 & 11.67 & 1.35 & 1.48 & 22.23 & 16.55 & 8.50 & 7.57 & 6.59 & 6.45 & 20.30 & 19.15 & 12.93 & 6.09 \\
\hline \multicolumn{2}{|c|}{ PMR-71 } & 40.67 & 39.24 & 7.25 & 6.81 & 1.33 & 1.29 & 12.43 & 13.97 & 8.80 & 8.50 & 6.19 & 6.19 & 19.12 & 15.14 & 3.99 & 3.85 \\
\hline \multicolumn{2}{|c|}{ PRP-801 } & 87.33 & 84.28 & 13.46 & 12.99 & 1.32 & 1.27 & 20.79 & 21.97 & 8.22 & 7.91 & 6.84 & 6.84 & 20.33 & 20.10 & 12.36 & 11.93 \\
\hline \multicolumn{2}{|l|}{ KS-205 } & 74.67 & 72.05 & 12.33 & 12.73 & 1.65 & 1.54 & 15.76 & 19.30 & 8.97 & 8.66 & 8.11 & 8.11 & 17.48 & 16.87 & 8.24 & 7.95 \\
\hline \multicolumn{2}{|l|}{ KS-501 } & 55.00 & 53.08 & 10.76 & 9.38 & 1.28 & 1.20 & 13.63 & 13.15 & 9.24 & 8.91 & 8.51 & 8.51 & 15.69 & 14.64 & 6.47 & 11.48 \\
\hline \multicolumn{2}{|l|}{ KS-156 } & 94.00 & 101.02 & 13.46 & 14.18 & 1.28 & 1.37 & 14.93 & 27.67 & 8.47 & 9.06 & 8.04 & 7.86 & 20.83 & 22.02 & 15.66 & 14.76 \\
\hline \multicolumn{2}{|l|}{ KS-210 } & 70.75 & 65.14 & 12.27 & 11.94 & 1.37 & 1.30 & 16.09 & 15.17 & 8.49 & 8.01 & 7.77 & 7.77 & 19.76 & 17.81 & 5.27 & 6.87 \\
\hline \multicolumn{2}{|l|}{ VRP-6 } & 85.67 & 80.71 & 12.67 & 11.62 & 1.46 & 1.38 & 21.89 & 21.26 & 9.50 & 8.95 & 7.37 & 7.37 & 18.90 & 18.62 & 9.38 & 11.45 \\
\hline \multicolumn{2}{|l|}{ VRP-5 } & 96.33 & 77.92 & 14.04 & 10.68 & 1.35 & 1.30 & 23.69 & 14.85 & 9.53 & 8.82 & 7.34 & 7.59 & 22.47 & 16.40 & 13.13 & 12.67 \\
\hline \multicolumn{2}{|l|}{ VRP-7 } & 90.07 & 82.91 & 13.79 & 11.40 & 1.44 & 1.05 & 26.13 & 24.82 & 8.70 & 8.65 & 7.66 & 7.92 & 20.40 & 17.81 & 12.04 & 7.83 \\
\hline VRP-9 & & 82.70 & 76.95 & 12.33 & 12.66 & 1.38 & 1.31 & 18.73 & 21.11 & 9.36 & 8.08 & 7.59 & 6.59 & 15.54 & 18.45 & 12.18 & 12.29 \\
\hline Arkel ( & ck) & 88.00 & 90.77 & 12.40 & 13.23 & 1.12 & 1.27 & 19.66 & 19.75 & 9.69 & 8.89 & 7.92 & 7.34 & 18.90 & 19.28 & 8.31 & 8.84 \\
\hline Mean & & 79.47 & 75.38 & 12.28 & 11.58 & 1.39 & 1.33 & 19.77 & 19.11 & 8.93 & 8.46 & 7.33 & 7.32 & 19.39 & 18.42 & 10.03 & 9.54 \\
\hline C.V. $\%$ & & 3.92 & 4.04 & 2.18 & 1.96 & 7.51 & 6.41 & 3.31 & 4.10 & 2.25 & 4.60 & 9.87 & 6.54 & 4.90 & 4.90 & 5.42 & 5.41 \\
\hline S.E.m \pm & & 1.80 & 1.76 & 0.15 & 0.13 & 0.06 & 0.05 & 0.38 & 0.45 & 0.12 & 0.22 & 0.42 & 0.28 & 0.55 & 0.52 & 0.31 & 0.30 \\
\hline C.D. at & & 5.15 & 5.04 & 0.44 & 0.37 & 0.17 & 0.14 & 1.08 & 1.29 & 0.33 & 0.64 & 1.19 & 0.79 & 1.57 & 1.49 & 0.90 & 0.85 \\
\hline Range & Lowest & 40.67 & 39.24 & 7.25 & 6.81 & 1.12 & 1.05 & 12.43 & 13.15 & 7.98 & 7.57 & 6.13 & 6.13 & 15.54 & 14.64 & 3.99 & 3.85 \\
\hline & Highest & 106.33 & 101.02 & 14.57 & 14.18 & 1.69 & 1.61 & 29.13 & 27.67 & 9.77 & 9.27 & 8.51 & 8.51 & 23.18 & 22.02 & 15.66 & 14.76 \\
\hline
\end{tabular}


Table.4.3 Estimates of range, grand mean, phenotypic (PCV), genotypic (GCV), and environmental (ECV) coefficient of variation, heritability in broad sense, genetic advance $(\mathrm{Ga})$ and genetic advance in per cent of mean for eight characters in vegetable pea

\begin{tabular}{|l|c|c|c|c|c|c|c|c|c|}
\hline $\begin{array}{l}\text { Characters } \\
\text { Components }\end{array}$ & Year & $\begin{array}{c}\text { Height } \\
\text { of plant } \\
\text { (cm) }\end{array}$ & $\begin{array}{c}\text { No. of } \\
\text { branches } \\
\text { /plant }\end{array}$ & $\begin{array}{c}\text { Pod } \\
\text { width } \\
\text { (cm) }\end{array}$ & $\begin{array}{c}\text { Number } \\
\text { of pods } \\
\text { / plant }\end{array}$ & $\begin{array}{c}\text { Pod } \\
\text { length } \\
\text { (cm) }\end{array}$ & $\begin{array}{c}\text { No. of } \\
\text { grains / } \\
\text { pod }\end{array}$ & $\begin{array}{c}\text { No. of } \\
\text { nodes } \\
\text { per } \\
\text { /plant }\end{array}$ & $\begin{array}{c}\text { Pod } \\
\text { Yield } \\
\text { (t/ha) }\end{array}$ \\
\hline PCV & Y1 & 20.86 & 15.26 & 12.08 & 23.43 & 6.87 & 12.49 & 10.72 & 35.34 \\
\cline { 2 - 10 } & Y2 & 20.66 & 16.25 & 11.32 & 22.04 & 7.29 & 10.94 & 10.63 & 35.39 \\
\hline GCV & Y1 & 20.49 & 15.10 & 9.46 & 23.19 & 6.49 & 7.65 & 9.53 & 34.92 \\
\hline & Y2 & 20.26 & 16.13 & 9.33 & 21.65 & 5.66 & 8.77 & 9.43 & 34.97 \\
\hline Heritability (\%) & Y1 & 96.47 & 97.96 & 61.35 & 98.00 & 89.24 & 37.56 & 79.06 & 97.65 \\
\hline in broad sense & Y2 & 96.17 & 98.55 & 67.96 & 96.55 & 60.26 & 64.27 & 78.70 & 97.66 \\
\hline Genetic advance & Y1 & 32.94 & 3.78 & 0.21 & 9.35 & 1.13 & 0.71 & 3.38 & 7.13 \\
\hline & Y2 & 30.85 & 3.82 & 0.21 & 8.38 & 0.77 & 1.06 & 3.17 & 6.79 \\
\hline Genetic advance & Y1 & 41.45 & 30.79 & 15.26 & 47.30 & 12.64 & 9.66 & 17.45 & 71.09 \\
\hline in per cent of & Y2 & 40.93 & 32.99 & 15.85 & 43.83 & 9.05 & 14.49 & 17.23 & 71.19 \\
\hline mean & & & & & & & & & \\
\hline
\end{tabular}

*, **: Significant at $5 \%$ and $1 \%$ probability level, respectively.

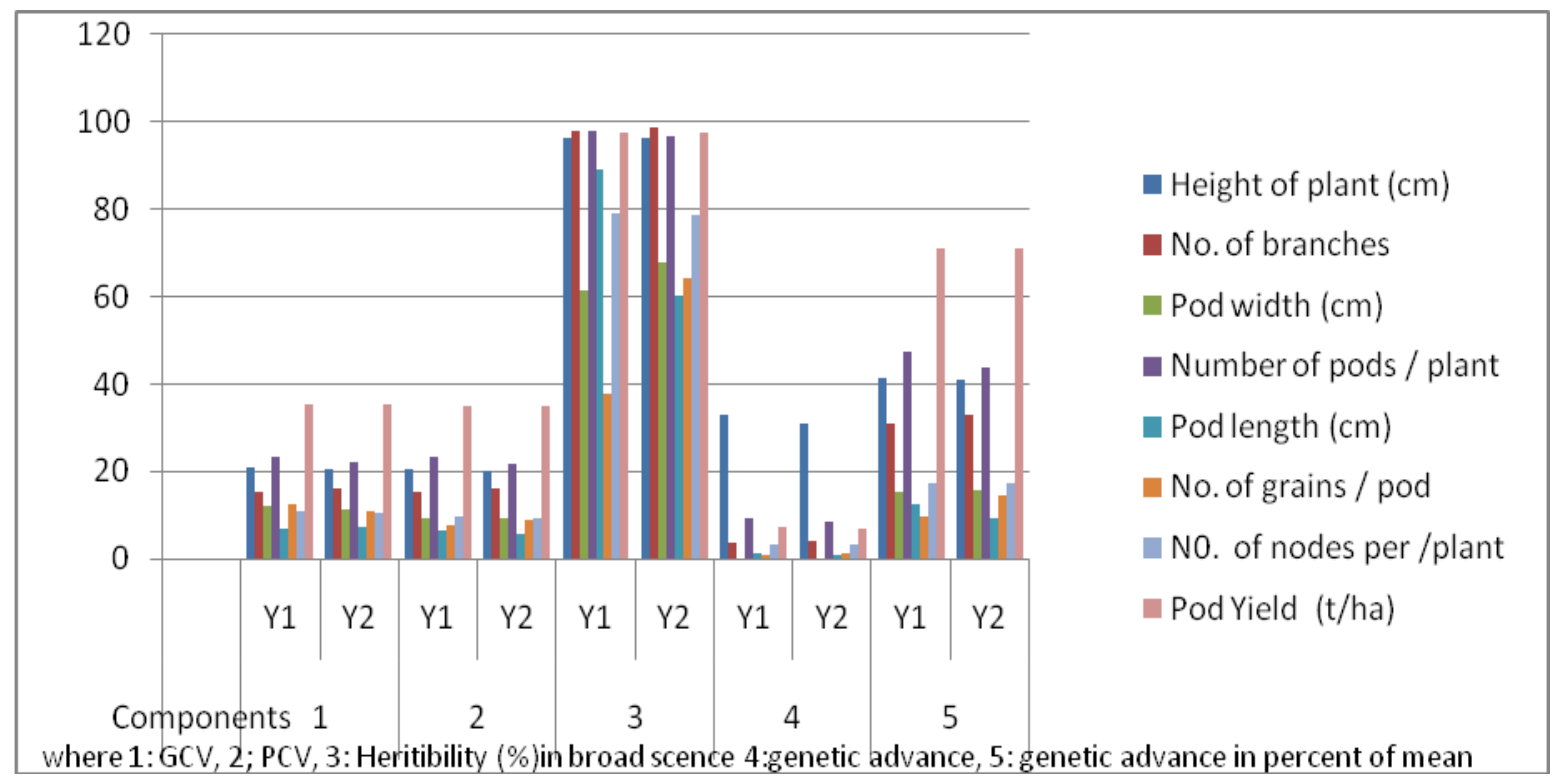

The high estimates of PCV and GCV for pod yield, number of pods per plant and height of plant suggest substantial variability for the traits thereby ensuring ample scope for improvement of these traits through selection Chaudhary et al., (2010) and Kumar et al.,
(2010) have also reported high GCV and PCV for these characters.

\section{Heritability and genetic advance}

The coefficient of variation alone cannot be 
used for partitioning the components of variation (Burton 1952). Heritability in broad sense is of significance to the breeders as its magnitude indicates the reliability with which a genotype can be recognized by its phenotypic expression. Therefore, genetic coefficient of variation together with heritability estimates would give the appropriate prediction of the amount of advance to be expected from selection.

High estimates of heritability were (Table-4) observed for height of plant (96.47 and 96.17 $\%)$, number of branches per plant (97.96 and $98.55 \%)$, number of pods per plant $(98.00$ and $96.55 \%$ ), pod yield (97.65 and $97.66 \%$ ), protein (95.03 and $97.23 \%$ ), ascorbic acid (95.03 and $94.97 \%$ ), ash content (88.08 and $88.15 \%)$ and moisture (80.47 and $80.52 \%)$ during both the years, respectively. While, high estimates of heritability showed in pod length $(89.24 \%)$ in $\mathrm{Y}_{1}$ only. Heritability estimates were moderate for number of nodes per plant (79.06 and $78.70 \%$ ), and pod width $(61.35$ and $67.96 \%)$ during both the years $\left(\mathrm{Y}_{1}\right.$ and $\mathrm{Y}_{2}$ ), respectively. Whereas, moderate estimates of heritability $(64.27 \%)$ showed in number of grains per pod in $\mathrm{Y}_{2}$. The low estimates of low heritability obtained for number of grains per pod $(37.56 \%)$ in $Y_{1}$.

High heritability coupled with high genetic advance were observed for pod yield per plant, height of plants, number of branches per plant, number of pods per plant, protein and ash content during both the years which revealed that these characters are governed by additive gene action and phenotypic selection would be effective for the improvement of characters. Moderate heritability along with moderate genetic advance was observed for pod width and number nodes per pod. Presence of high heritability for above mentioned traits indicated that large proportion of phenotypic variance was attributable to the genotypic variance and the differences for the trait among the genotypes were real. Therefore, selection for these traits on the basis of phenotypic expression could be relied upon. Gupta et al., (2006), Kumar et al., (2013) and Sharma et al., (2013) have also reported high heritability and genetic advance for growth and yield traits which corroborate the present findings.

Finally it may be concluded that KS-156 produced significantly higher pod yield, during both the years. The wide range of genetic variation was observed for all the characters among the genotypes. The characters like pod yield per plant, height of plants, number of branches per plant, number of pods per plant, protein and ash content are governed by additive gene action and phenotypic selection would be effective for the improvement of characters.

\section{References}

Alam, M. K.; Uddin, M. M.; Ahmed, M.; Latif M. A. and Rahman M. M. (2010) Growth and green pod yield of garden pea varieties under different nutrient levels. J. Agrofor. Environ. 4 (1): 105107.

Anonymous (2016). Horticulture Data base, National Horticulture Board, Gurgaon, Haryana, India.

Burton, G. W. (1952). Quantitative inheritance in grasses, Proc. 6th INT. Grassld. Congr. 1: 277-283.

Chadha, S.; Rameshwar; Saini, J.P. and Sharma, S (2013), Performance of Different Varieties of Pea (Pisum sativum L.) under Organic Farming Conditions in Mid Himalayas. International J. Agric. and Food Sci. Tech., 4(7): 733-738.

Chadha, S.; Sharma, R.; Chaudhary, D. R. and Vidyasagar (2008). Genetic variability studies in summer pea under cold desert areas of North-Western 
Himalayas. Agrl. Sci. Digest. 28 (1):1013.

Choudhary, H.; Verma, M. K. and Sofi, A. A. (2010). Genetic variability, heritability and genetic advance for yield components in garden pea. Pant. J. Res. 8 (2): 195-197.

Gupta, A. J. and Singh, Y. V. (2007). Evaluation of garden pea (Pisum sativum) genotypes for earliness, yield and quality attributes. Haryana $J$. Hortic. Sci., 36(1\&2) 106-110.

Gupta, A. J.; Singh, Y. V. and Verma, T. S. (2006). Genetic variability and heritability in garden pea (Pisum sativum L.) Indian J. Hort., 63 (3): 332334.

Gupta, A. J.; Singh, Y. V; Hussain, K; Bhat, S. A; Bhat, F. N. and Singh, T. K (2007). Character association and selection parameters in garden pea (Pisum sativum L.). Environment and Ecology. 25 (2): 331-335.

Kalloo, G.; Rai, M.; Singh, J.; Verma, A. and Kumar, R. (2005). Morphological and biochemical variability in vegetable pea (Pisum sativum L.).Veg. Sci., 32 (1): 1923.

Katoch V.; Singh, P.; Devi, B. M. and Sharma, J. K. (2015). Heritability and genetic advance, correlation coefficient and path coefficient analysis in garden pea (Pisum sativum L.). Article-Impact Facter: 6851.

Khan, T.N.; Ramzan, A.; Jillani, G.; and Mehmood, T. (2013) Morphological performance of peas (Pisum sativum L.) genotypes under rainfed conditions of potowar region. J. Agric. Res., 51(1): 51-60.

Kumar, D.; Malik, S.; Singh, S. K. and Kumar, M. (2013). Genetic variability, heritability and genetic advance for seed yield and yield components in garden pea (Pisum sativum L.). Vegetos. 26 (2): $182-184$.

Kumar, J.; Ashraf, N. and Pal, K. (2010). Variability and character association in garden pea (Pisum sativum L.). Progressive Agri. 10 (1):124-131.

Murtaza, G.; Asghar, R.; Ahmad, S. and Majid, S. A. (2007). The yield and yield components of pea (Pisum sativum L.) as influenced by salicylic acid Pak. J. Bot., 39(2): 551-559,

Panse, V. G. and Shukhatme, P. V. (1967). Statistical method for agriculture workers, 2 eds. Indian Council of Agricultural Research, New Delhi.

Sharma, M. K.; Chandel, A. and Kohli, U. K. (2011). Genetic evaluation correlation coefficients and path analysis in garden pea (Pisum sativam L.). Prog. Agril. 11 (2): 434-439.

Sharma, V. K. and Sharma, B. B. (2013). Genetic variability, heritability and genetic advance studies in garden pea under mid hill condition of Garhwal Himalaya. Environmental and Ecology., 31 (1A) : 296-301.

Singh, R. and Singh, P.M. (2011). Effect of sowing dates and varieties on yield and quality of garden pea seed. Veg. Sci. 38(2):184-187.

\section{How to cite this article:}

Jai Vardhan Raj, V. M. Prasad, Vijay Bahadur, Rajneesh Srivastava and Devi Singh. 2020. Genetic Analysis for Growth and Yield Traits of Different Genotypes of Pea (Pisum sativum L.) under Prayagraj agro-climatic Condition. Int.J.Curr.Microbiol.App.Sci. 9(03): 797-805. doi: https://doi.org/10.20546/ijcmas.2020.903.094 